\title{
Biocompatible Titanium Alloys used in Medical Applications
}

\author{
MADALINA SIMONA BALTATU ${ }^{1}$, CATALIN ANDREI TUGUI ${ }^{1}$, MANUELA CRISTINA PERJ $\mathrm{U}^{1,2}$, MARCELIN BENCHEA ${ }^{3}$, \\ MIHAELA CLAUDIA SPATARU 4 , ANDREI VICTOR SANDU ${ }^{1,2}$, PETRICA VIZUREANU ${ }^{1,2 *}$ \\ ${ }^{1}$ Gheorghe Asachi Technical University of lasi, Faculty of Materials Science and Engineering, 41 D. Mangeron Str., 700050, Iasi, \\ Romania \\ ${ }^{2}$ Centre of Excellence Geopolymer \& Green Technology School of Materials Engineering, University Malaysia Perlis, Kompleks \\ Pengajian Jejawi 2, 02600 Arau, Perlis \\ ${ }^{3}$ Gheorghe Asachi Technical University of lasi, Faculty of Mechanical Engineering, 51 D. Mangeron Blvd., 700050, Iasi, Romania \\ ${ }^{4}$ Ion Ionescu de la Brad University of Agricultural Sciences and Veterinary Medicine of lasi, 3 Mihail Sadoveanu Alley, 700490, \\ Iasi, Romania
}

\begin{abstract}
At global level, there is a continuing concern for the research and development of alloys for medical and biomedical applications. Metallic biomaterials are used in various applications of the most important medical fields like orthopedic, dental and cardiovascular. The main metallic biomaterials used in human body are stainless steels, Co-based alloys and Ti-based alloys. Titanium and its alloys are of greater interest in medical applications because they exhibit characteristics required for implant materials, namely, good mechanical properties (less elasticity modulus than stainless steel or $\mathrm{CoCr}$ alloys, fatigue strength, high corrosion resistance), high biocompatibility. The aim of this review is to describe and compare the main characteristics (mechanical properties, corrosion resistance and biocompatibility) for latest research of nontoxic Ti alloys biomaterials used for medical field.
\end{abstract}

Keywords: Ti alloys, biomaterials, mechanical properties, corrosion resistance

Biomaterials had an important role in many aspects of the contemporary medical field through considerable progress over time. Applications of biomaterials in the field of medicine are primarily due to the requirements of medical practice, but also to the continuous evolution of the sciences. A permanent correlation of research in the fields of chemistry, biology, engineering, and medicine leads the science of biomaterials to obtain new materials that can address the many medical problems that exist today [1-4].

Materials used as biomaterials are: metallic, ceramic, polymeric and composite. The most common and known are metallic biomaterials. This category includes pure metals, metal alloys and intermetallic compounds [5-7], according to table 1 .

Biomaterials are products of organic or inorganic nature that find various uses in different parts of the human body as artificial valves in the heart, stents in blood vessels, replacement implants in shoulders (fig.1), knees, hips, ears, dental structures etc. [8-10].

Titanium alloys are widely used in medicine, cardiology and dentistry. In medicine, they are used for implant devices that replace hard tissue. Compared to stainless steels and Co-based alloys, titanium alloys have a better biocompatibility [12]. Stainless steels and $\mathrm{CoCr}$ alloys are prone to corrosion, releasing metal ions into the body that can cause side effects in dentistry, titanium initial was used for dental implants, and at last years, have been diversified in dental prosthetics and orthodontics. There are three types of dental implant: osseointegrated, miniimplant for orthodontic anchorage and zygomatic. Each group needs different mechanical properties and must be made of C.P Ti or a Ti-based alloys with non toxic elements. Titanium dental implants have become the most widely

\begin{tabular}{|c|c|c|}
\hline \multirow[t]{2}{*}{1.} & \multirow[t]{2}{*}{ Pure metals } & Precious (Au, Ag, Pt) \\
\hline & & Invaluable $(\mathrm{Ti}, \mathrm{Ta}, \mathrm{W}, \mathrm{Nb})$ \\
\hline \multirow[t]{3}{*}{2.} & \multirow[t]{3}{*}{ Metallic alloys } & Austenitic stainless steels \\
\hline & & Titanium alloys (TiAl6V4, TiAI5Fe2,5) \\
\hline & & Cobalt-Crom alloys (with or without $\mathrm{W}, \mathrm{Mo}, \mathrm{Ni}$ ) \\
\hline \multirow[t]{2}{*}{3.} & \multirow{2}{*}{$\begin{array}{l}\text { Intermetallic } \\
\text { compounds }\end{array}$} & Dental amalgam \\
\hline & & Compounds or memory shape alloys \\
\hline
\end{tabular}

Table 1

CCLASSIFICATION OF METALLIC BIOMATERIALS [6]
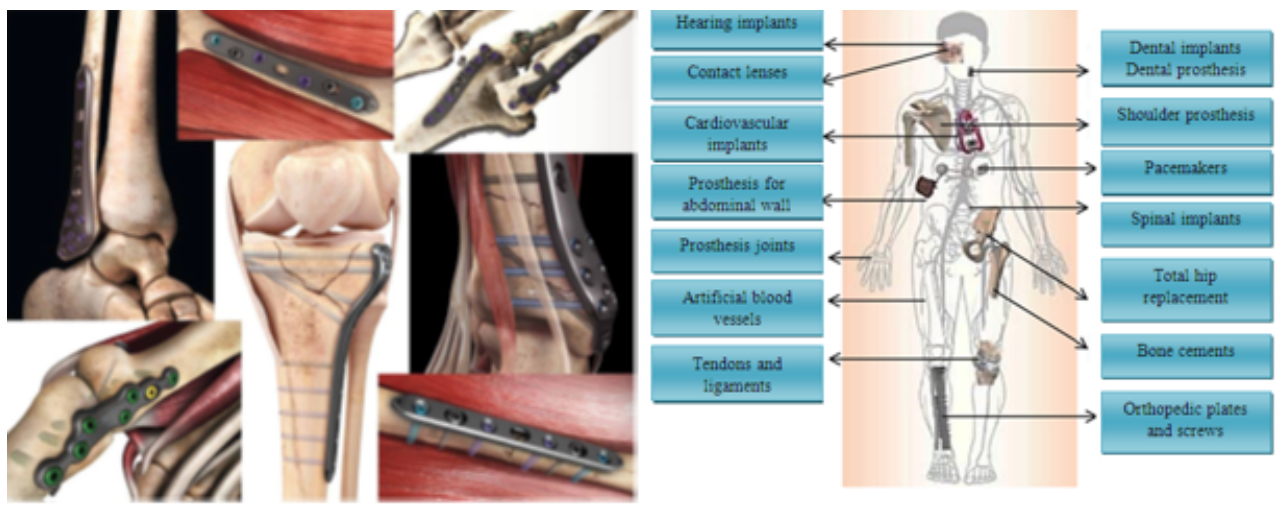

Fig.1. Representative example of application of metallic biomaterials: bone fixation devices [8-11] 
accepted and successfully used type of implant due to its propensity to osseointegrate [13-16].

In cardiovascular surgery, titanium-based materials are commonly used in the form of metallic stents (NiTi, TiNO), cardiac valve prostheses, pacemakers, and artificial hearts. The most commonly used material is nitinol, in the form of self-expanding stents, a form memory alloy that retains shape with its predetermined size and configuration [10, 17].

The area in which titanium is widely used is orthopedic applications. Examples from orthopedic applications include artiûcial hip joints, artiûcial knee joints, bone plates, screws for fracture ûxation, pins, bars, rods, wires, posts, expandable rib cages, spinal fusion cages, finger and toe replacements, maxi-facial prosthetics [13, 18].

Applications of biomaterials in the field of medicine are primarily due to the requirements of medical practice, but also to the continuous evolution of the sciences. A permanent correlation of research in the fields of chemistry, biology, engineering, and medicine leads the science of biomaterials to obtain new materials that can address the many medical problems that exist today [19].

\section{Titanium Alloys properties}

Titanium alloys must have high biocompatibility, good corrosion resistance and excellent mechanical properties (low density, low Young's modules [19-21]) for use in fields such as orthodontics and orthopedics, but also in cardiovascular and reconstructive purposes. Some titanium alloys receive more attention as biomaterials due to their high specific weight and good corrosion resistance, without allergic problems, and show the best biocompatibility between metallic biocompatible materials (fig. 2).

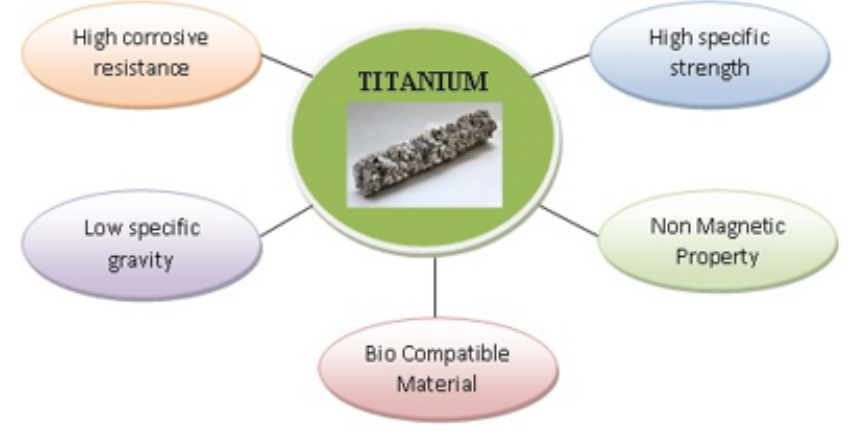

Fig. 2. Titanium properties for medical use [18]

Table 2

CRITICAL ANALYSIS OF THE BIOLOGICAL ASPECTS OF THE MAIN ALLOYING ELEMENTS FOR TITANIUM-BASED BIOMEDICAL ALLOYS [11]
Titanium has been found to be the only metallic biomaterial for bone integration and has a bioactive behavior (greatly improves the quality and duration of use of implants [22]) due to the slow increase of titanium hydrated oxide on the surface of the titanium implant leading to the incorporation of calcium and phosphorus $[13,23]$.

The influence of alloying elements in titanium alloys contributes to a wide range of different microstructural and mechanical properties. Thus, the alloying elements are divided into three categories: stabilizers $\alpha: \mathrm{C}_{1} \mathrm{~N}_{2}, \mathrm{O}_{2}$ Al; $\beta$ stabilizers: V, Nb, Mo, Ta, Fe, Mn, Cr, Co, W, Ni, Cu, $\mathrm{Si}^{\prime \prime}$ $\mathrm{H} 2$; neutral elements: $\mathrm{Zr}$, Sn, Hf, Ge, Th [11].

According to recent studies, since the 1990s, titanium alloys have been studied and improved with various alloying elements. The authors correlated the values of the mechanical characteristics with X-ray diffraction results and pointed out that low elastic modulus alloys are due to the full presence of the $\beta$ phase [12]. Types of Ti-based alloys systems in different combination with biocompatible elements: Ti-Al, Ti-Al-Sn, Ti-Al-Zr, Ti-Al-Sn-Cu, Ti-Cu-Zr $(\alpha$ phase) [24], Ti-Al-Mn, Ti-Al-V, Ti-Al-Mo, Ti-Al-Mo-V, Ti-AlMo-Cr $(\alpha+\beta$ phase) [25], Ti-Mo, Ti-Nb, Ti-Ta, Ti-Zr, Ti-Zr$\mathrm{Nb}, \mathrm{Ti}-\mathrm{Sn}-\mathrm{Nb}, \mathrm{Ti}-\mathrm{Nb}-\mathrm{Ta}-\mathrm{Zr}$ ( $\beta$ phase) [26], Ti-Mo-Si, Ti-MoZr-Ta, Ti-Al-Zr, Ti-Al-Sn-Cu, Ti-Cu-Zr ( $\alpha$ phase ) [20], Ti-Al$\mathrm{Mn}$, Ti-Al-V, Ti-Al-Mo, Ti-Al-Mo-V, [25], Ti-Mo, Ti-Nb, Ti-Ti, TiZr, Ti-Zr-Nb, Ti-Sn-Nb, Ti-Mo-Si ( $\beta$ phase), Ti-Mo-Zr-Ta ( $\beta$ phase) [11].

Biomaterials have to meet certain requirements and take into account some important characteristics. Properties of interest in the use of these alloys are: mechanical properties, biocompatibility and corrosion resistance.

\section{Biocompatibility}

The biological biocompatibility of any implant, which is defined by its toxicity, carcinogenicity and metal sensitivity from the release of metal ions, must be quantified to decrease the patient's risk and failure of implants [27, 28].

According to the tissue reaction phenomena, the biocompatibility of orthopedic implant materials was classified into three categories by Heimke [29], such as biotolerant, showing distant osteogenesis (bone formation with indirect contact to the material); bioinert, showing contact osteogenesis (bone formation with direct contact to the material), and bioactive showing bonding osteogenesis (bone formation with chemical or biological bonding to the material).

The biocompatibility of these alloys is influenced by alloying elements. Table 2 lists the main alloying elements of titanium and its influence.

\begin{tabular}{|c|c|}
\hline Chemical element & Biological aspects \\
\hline Molybdenum & $\begin{array}{l}\rightarrow \text { the human body contains about } 0.07 \mathrm{mg} \text { of molybdenum; } \\
\rightarrow \text { is an essential element for a number of important enzymes of cellular metabolism; } \\
\rightarrow \text { is less toxic than many other metals ( } \mathrm{Co}, \mathrm{Cr} \text { and } \mathrm{Ni}) \text {. }\end{array}$ \\
\hline Tantalum & $\begin{array}{l}\rightarrow \text { has excellent corrosion resistance in a large number of acids; the corrosion resistance } \\
\text { of tantalum is approximately the same as that of the glass; } \\
\rightarrow \text { is non-toxic element and the most biocompatible metals used for implantable devices. }\end{array}$ \\
\hline Zirconium & $\begin{array}{l}\rightarrow \text { is found in the body on average } 1 \mathrm{mg} ; \\
\rightarrow \text { metal zirconium has the highest biocompatibility in the body of all metals and } \\
\text { Zirconium compounds have a low toxicity. }\end{array}$ \\
\hline Aluminum & $\begin{array}{l}\rightarrow \text { presents acute toxicity at very high doses; } \\
\rightarrow \text { many studies show that excessive exposure to aluminum may increase the risk of } \\
\text { breast cancer and other neurological conditions such as Alzheimer's disease. }\end{array}$ \\
\hline Niobium & $\begin{array}{l}\rightarrow \text { a recent study shows that researchers have found that niobium ions are the most } \\
\text { toxic, along with cobalt, capable of inducing DNA damage and can cause immune } \\
\text { cell death; } \\
\rightarrow \text { this element should be treated with care, especially when used with multiple alloying } \\
\text { elements. }\end{array}$ \\
\hline
\end{tabular}


In his work, D.R.N. Correa et al. [30] showed the cytotoxicity levels of Ti-15Zr-xMo alloys, seeing were within a tolerable range for biomedical purposes, (fig.3).

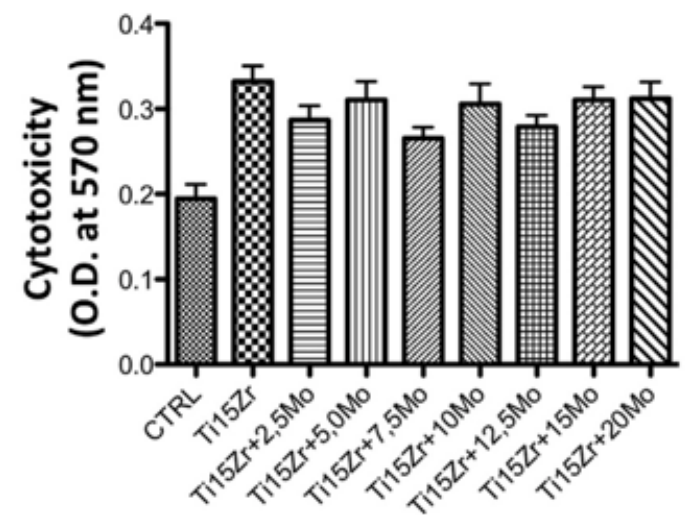

Fig. 3. Cytotoxic test results for Ti-15Zr-Mo alloys

The biocompatibility of new titanium alloys (Ti13Nb13Zr) for biomedical applications were investigated in this study by A. Stroz etal. [31]. To determine the biocompatibility of the Ti13Nb13Zr alloy before and after electrochemical modification examinations according to the ASTM F756-00 standard were performed. Based on this standard the hemolytic index below 2 evidences that material is nonhemolitic. The obtained results of hemolysis test revealed the value of the hemolytic index of $0.30(0.08)$ for the Ti13Nb13Zr alloy before modification and 0.00 for anodically formed SW NTS (single-walled nanotubes) on the alloy surface. The latter value proves that the proposed surface modification completely eliminates hemolysis process and ensures excellent hemocompatibility of the porous Ti13Nb13Zr alloy with SWNTs.

Ti-Mo alloys group has superior corrosion resistance due to thin, compact and extremely stable titanium dioxide film that forms in seconds after contact with the environment.

\section{Mechanical properties}

The mechanical properties were studied by Xu V., on a dental alloy, metallic injection molding (MIM) Ti-12Mo using non-spherical titanium, molybdenum powders and a intentionally designed binder. The properties of density, hardness and traction were characterized. The density was measured by the Archimedes method, and the hardness by a desktop HDI-1875 Rockwell hardness tester [32]. The authors observed that the sintered density shows a clear dependence on temperature, which increases rapidly before reaching $1400^{\circ} \mathrm{C}$ and become stable afterwards.

The tensile strengths, ductility, elastic modulus and hardness of the MIM-fabricated Ti-12Mo are shown in figure $.4 \mathrm{vs}$. sintering temperature. The hardness, tensile strength and elongation all increase with increasing temperature before reaching $1400^{\circ} \mathrm{C}$ and decline slightly afterwards. The elastic modulus increases similarly with increasing sintering temperature but is stabilized at about $73.2 \pm 5.1$ GPa when sintered at or above $1400^{\circ} \mathrm{C}$. The optimum sintering temperature is therefore determined to be $1400^{\circ} \mathrm{C}$, which led to good tensile properties.

Studies have shown that alloys based on Ti-Mo alloys with various biocompatible elements exhibit superior mechanical properties such as high tensile strength and a much lower modulus of elasticity close to that of human bone compared to other classical biomaterials. The values of the longitudinal elastic modulus of the Ti-Mo alloys compared to the classical ones are shown in figure 5 . The alloys of the $\beta$ type have much lower values of the longitudinal elastic modulus compared to the $\alpha$ or $\alpha+\beta$ alloys, which is why research and their development is a priority for researchers [7, 11, 33-35].

D.R.N. Correa et al. [30] studied the mechanical properties (density, hardness and Young's modulus) of Ti15Zr-Mo alloy, and he found that this alloy has excellent mechanical compatibility for use in biomedical implants.

In the case of the Ti77Nb17Ta6 alloy, the authors [35] note that the strength and hardness have increased with
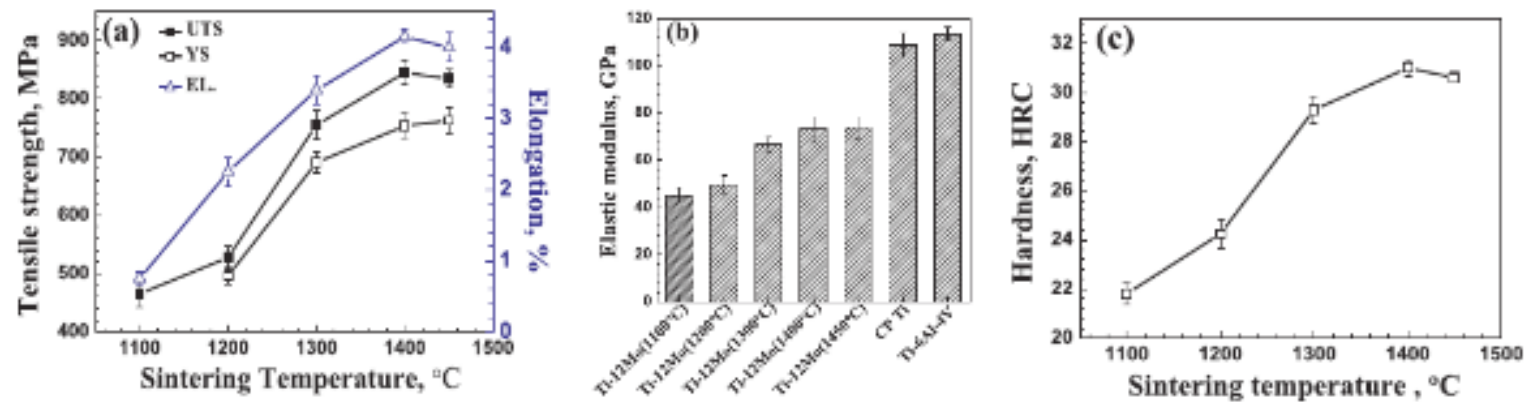

Fig. 4. Mechanical properties of MIM-fabricated Ti-12Mo specimens sintered at each temperature for $2 \mathrm{~h}$ : (a) tensile properties; (b) elastic modulus; (c) hardness [32]

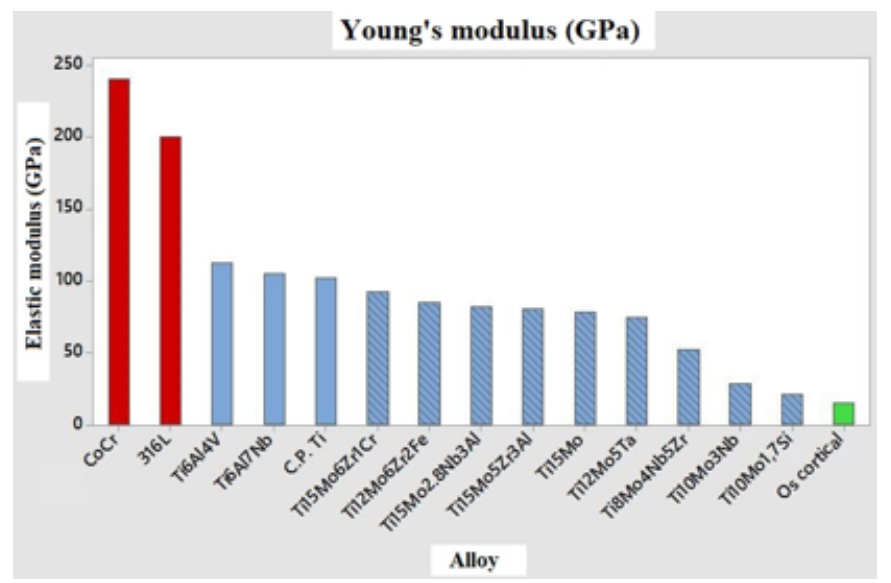

Fig. 5. Values of the modulus of elasticity for different titanium alloys [11, 33] 

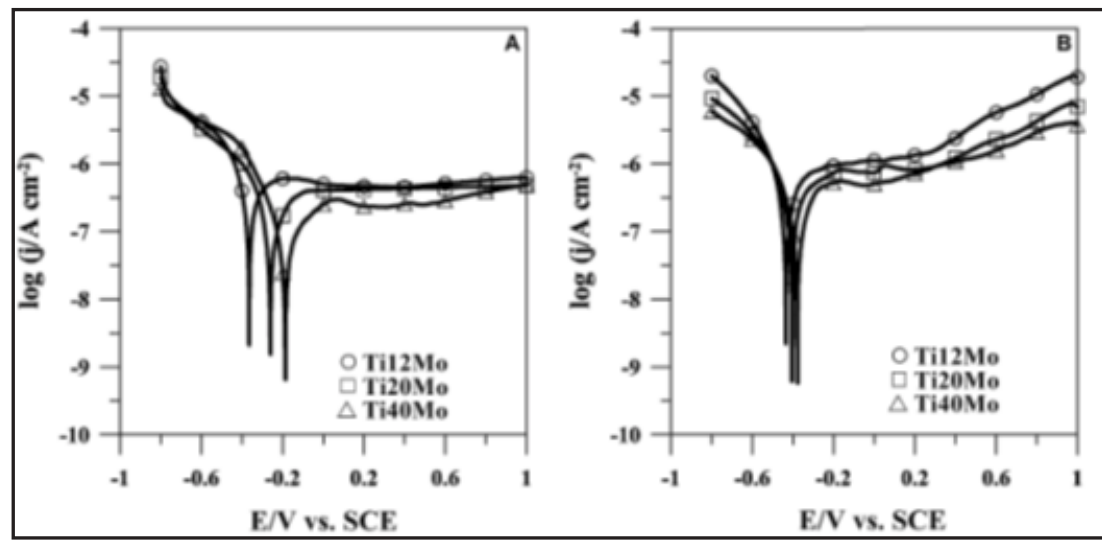

Fig. 6. Potentiodynamic polarization curves of TiMo alloys in (A) Ringer's solution, and (B) acidic Ringer's solution

at room temperature. $\mathrm{v}=0.5 \mathrm{mV} \mathrm{s}^{-1}$. Curves determined from individual samples
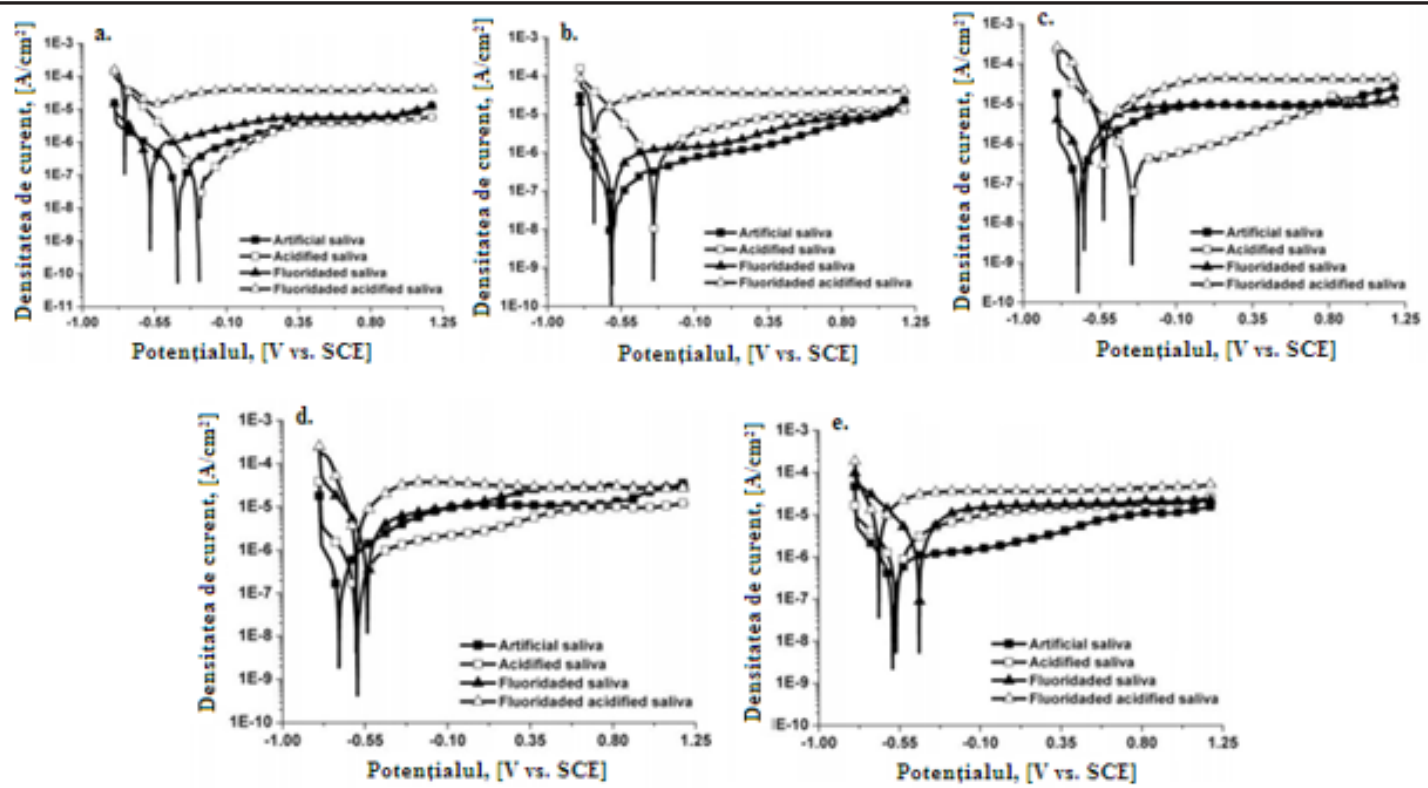

Fig. 7. Potentiodynamic polarization curves in different environments: a) Ti6Al7Nb;

b) Ti30Ta; c) Ti40Ta; d) Ti50Ta; e) Ti60Ta [11]

the increase in $\beta$-phase stability while ductility and Young's modulus have decreased. Mechanical properties have a direct correlation with $\beta$-phase stability.

In his work, Mohsin Talib Mohammed [36] studied the mechanical characteristics of the Ti-15Zr-12Nb (TZN), alloy was manufactured using non-consumable vacuum arc melting method. The mixture of sponge Ti, zirconium chips and niobium powder is used as raw materials. The melting process was carried out in copper crucible under ultrahigh purity argon gas. Many researchers consider that low Young's modulus ( $E$ ) is an imperative aspect for any specific biomaterials [35, 36].

\section{Corrosion resistance}

Corrosion resistance is an essential feature of titanium and its alloys, due to its thin, compact and extremely stable titanium dioxide film that forms in seconds after contact with the environment. Thus, due to the very good corrosion resistance, titanium is used in medicine, resists water, acids or salt solutions, having a comparable behavior to platinum in the case of chemical corrosion $[2,11]$.

The corrosion resistance of TiMo alloys has been described in the many studies [35-42].

G. Bolat et al. [37], carried out experiments on three TiMo alloys with different composition (12, 20 and 40 wt.\% of Mo) that have been synthesized by cold crucible levitation melting in an induction furnace. Molybdenum is used as alloying element for titanium because it has good thermodynamic stability and considered to be instrumental in regulating the $\mathrm{pH}$ balance in the body.
The tests were conducted in two artificial physiological solutions based on the Ringer's solution (fig.6). All components were of analytical grade, and Milli-Q deionised water [37].

Another comparative study between Ti6Al7Nb and Ti30Ta, Ti40Ta, Ti50Ta, Ti60Ta, was performed in different types of saliva (artificial saliva, acidified saliva, fluorinated saliva). The polarization curves in the different environments are shown in figure 7 [11, 37-39].

The Ti6Al7Nb alloy exhibited lower corrosion resistance and a less stable oxide layer in the fluorinated saliva. TiTa alloys have shown a high corrosion resistance due to the formation of $\mathrm{Ta}_{2} \mathrm{O}_{5}$ oxide on the surface of the alloys, which has contributed to increased corrosion protection.

Passivation of these alloys is influenced by the presence of alloying elements as well as the presence of impurities in the material. Although the titanium, in the context of the electrochemical series, is a metal that should corrode strongly due to the formation of the oxide layer, it remains passive in the human body, which makes it very used in medical applications [11, 39-43].

\section{Conclusions}

Our research confirms previous results that the Ti-based alloys is a prospective candidate for biomedical applications due to its good mechanical and corrosion properties, ,ore over the following conclusions may be drawn:

Analysis of current research has provided information on all alloying elements used for titanium alloys with possible medical applications. The alloying elements have 
been studied in terms of influence on mechanical and chemical properties.

Ti-Mo alloys with different biocompatible elements exhibitsuperior mechanical properties such as high tensile strength and a much lower modulus of elasticity close to that of human bone compared to other classical biomaterials.

Ti-Mo alloys group has superior corrosion resistance due to thin, compact and extremely stable titanium dioxide film that forms in seconds after contact with the environment.

Acknowledgements: This work was supported by a grant of the Romanian Ministery of Research and Innovation, CCCDI -UEFISCDI, project number PN-III-P1-1.2-PCCDI-2017-0239 / 60PCCDI 2018, within PNCDI III.

\section{References}

1.SAENZ DE VITERI, V., FUENTES, E., Titanium and Titanium Alloys as Biomaterials, Chapter 5, 2013.

2.PARK, J.B., BRONZINO, J.D., Biomaterials: principles and applications, CC Press, 2002, p. 241.

3.RAMAKRISHNA, S., MAYER, J., WINTERMANTEL, E., LEONG, K.W., Composites Science and Technology 61, no. 3, 2001, p. 1189.

4. WISE, D.L., Biomaterials engineering and devices, Human Press, 1, 2000, p. 307.

5. ANTONIAC I., Handbook of Bioceramics and Biocomposites, 2016, p.705.

6. CIOBANU, M.G., CARJA, G., Performantica, lasi, 2010, p. 240.

7. LUPESCU, S., ISTRATE, B., MUNTEANU, C., MINCIUNA, M.G., FOCSANEANU, S., EARAR, K., Rev. Chim. (Bucharest), 68, no. 6, 2017, p.1408.

8. SCHOLZ, M.S., BLANCHFIELD, J.P., BLOOM, L.D., COBURN, B.H., ELKINGTON, M., FULLER, J.D., GILBERT, M.E., MUFLAHI, S.A., PERNICE, M.F., RAE, S.I., TREVARTHEN, J.A., WHITE, S.C., WEAVER, P.M., BOND, I.P, 71, 2011, p. 1791-1803.

9. BOMBAC, D.M., BROJAN, M., FAJFAR, P., KOSEL, F., TURK, R., Materials and Geoenvironment, 54, no.4, 2007, p. 471.

10. GEETHA, M., SINGH, A.K., ASOKAMANI, R., GOGIA, A.K., Mater. Sci., 54, 2009, p. 397.

11. CERCEL, M.S. (BALTATU), Teza de doctorat, Contributii privind îmbunãtãtirea proprietãtilor aliajelor Ti-Mo destinate aplicatiilor medicale, 2017, p. 26.

12. MARKHOFF, J., KROGULL, M., SCHULZE, C., ROTSCH, C., HUNGER, S., BADER, R., Fibroblasts and Macrophages, Mat., 10, no. 52, 2017, p. 17.

13. ELIAS, C.N., LIMA, J.H.C., VALIEV, R.,MEYERS, M.A., JOM, 2008, 60, no.3. p. 46.

14. MORAIS L.S., SERRA G. G. MULLER C. A., ANDRADE L. R., PALERMO ELISABETE F.A., ELIAS N. C., MEYERS M., Acta Biomaterialia, 3, 2007, p. 331.

15. SAVIN, A., STEIGMANN, R., IFTIMIE, N., NOVY, F., VIZUREANU, P., CRAUS, M.L., FINTOVA, S., Mat. Sci. and Eng, 147, no. 2016 p. 012030.
16. ISTRATE, B., MUNTEANU C., MATEI, M.N., OPRISAN, B., CHICET, D., EARAR, K., Mat. Sci. and Eng, 133, no. 1, p. 012010.

17. ACHITEI, D.C., ABDULLAH, M.M.A., SANDU, A.V., VIZUREANU, P., Engineering Materials 594, 2014, p.133.

18. *** http://www.supraalloys.com/medical-titanium.php.

19. NIINOMI, M., NARUSHIMA, T., NAKAI, M., Adv. in Met. Biomaterials; Springer, 2015.

20. Li, Y.H., YANG, C., ZHAO, H.D., QU, S.G., LI, X.Q., LI, Y.Y., Materials 7, 2014, p. 1709.

21. MOHSIN, T.M., ZAHID, A.K., ARSHAD, N.S., Int. J. Chem. Nucl. Metall. Mater. Eng. 8, 2014, p. 726.

22. CUMPATA, C., GANUTA, N., Revista romana de stomatologie, 57, no $1,2016$.

23. OLDANI, C., DOMINGUEZ, A., Recent Adv. in Arthroplasty, 2012, p. 149.

24. CSAKI, I., POPESCU, G., STEFANOIU, R., Rev. Chim. (Bucharest)., 64, no 7, 2013, p. 693.

25. OHNUMA, I., FUJ ITA, Y., MITSUI, H., ISHIKAWA, K., KAINUMA, R., ISHIDA, K., Acta Materialia 48, no 12, 2000, p. 3113.

26. GRANDIN M, BERNER H., DARD S. M., Materials 5, 2012, p. 1360.

27. GEPREEL, M.A.H, NIINOMI, M., J. of the Mec. behavior of Bio. Mat.

20, 2003, p. 407.

28. MINCIUNA, M.G., VIZUREANU, P., GEANTA, V., VOICULESCU, I., SANDU, A.V., ACHITEI, D.C., VITALARIU, A.M., Rev. Chim. (Bucharest), 66, 2015, p. 891.

29. HEIMKE, G., STOCK, D. Orthopedic Ceramic Implants, 4, 1984, p.19.

30. CORREA, D.R.N., KURODA, P.A.B., LOURENCO, M.L., FERNANDES, C.J.C., BUZALAF, M.A.R., ZAMBUZZI, W.F., GRANDINI, C.R., J. of Alloys and Compounds 749, 2018, p. 163.

31. STROZ, A., LOSIEWICZ, B., ZUBKO, M., CHMIELA, B., BALIN, K., DERCZ, G., GAWLIKOW SKI M., GORYCZKA T., Mat. Charac. 132, 2017, p.363.

32. XU, W., LU, X., WANG, L.N., SHI, Z.M., LV, S.M., QIAN, M., QU, X.H., J. of the Mec. Behavior of Bio. Mat., 88, 2018, p. 534.

33. CHEN, Q., THOUAS, G.A., Mat. Sci. and Eng. 87, 2015, p. 1.

34.*** http://www.medicut.de/en/services.html.

35. ABDELRAHMAN, H.H., MOHAMED, A.H.G., MOHAMED, K.G., AHMAD, M.H., SHERIF, H.K., Materials Science and Engineering C, 61, 2016, p.574.

36.MOHAMMED, M.T., Karbala Inter. J. of Modern Sci. 3, 2017, p. 224. 37. BOLAT, G., MARECI, D., CHELARIU, R., IZQUIERDO, J., GONZALEZ, S., SOUTO, R.M., Electrochimica Acta 113, 2013, p. 470.

38. OLIVEIRA, N.T.C., GUSTALDI, A.C., Acta Biomater. 51, 2009, p. 405. 39. OLIVEIRA, N.T.C., GUSTALDI, A.C., Corros. Sci. 50, 2008, p. 945. 40. MAGHERU, A.M., GHIBAN, B., GHIBAN, N., MICULESCU, M., U.P.B. Sci. Bull., Series B, 75, no. 3, p. 2013.

41. ALVEZ REZENDE, M.C.R., ROSIFINI ALVEZ, A.P., CODARO, E.N., MATSUMOTO DUTRA, C.A., J. Mater. Sci. Mater. Med. 18, 2007, p. 149. 42. KUMAR, S., SANKARA NARAYANAN, T.S.N., Am. J. Dent. 36, 2008, p. 500.

43. BALTATU, M.S., VIZUREANU, P., TIEREAN, M.H., MINCIUNA, M.G., ACHITEI, D.C., Adv. Mat. Research 1128, 2015, p.105.

$\overline{\text { Manuscript received: } 8.12 .2018}$ 